\title{
International academic mobility and patent filing in the country of origin
}

\author{
Paulette Siekierski 1 \\ Manolita Correia Lima ${ }^{1}$ \\ Felipe Mendes Borini 12 \\ 1 Escola Superior de Propaganda e Marketing / Programa de Mestrado e Doutorado em Gestão Internacional, São Paulo / SP - Brazil \\ 2 Universidade de São Paulo / Faculdade de Economia e Administração, São Paulo / SP - Brazil
}

\begin{abstract}
This article aims to verify the existence of a positive relationship between IAM (international academic mobility) and innovation (patent application) in the country of origin of the academic talent. The thesis is that there is a positive relationship to the country of origin. If in the first instance the positive effects of this relationship are for the countries of destination, there is a positive effect for the countries of origin, respecting the quality training of the academic trajectory and its position in national and international projection institutions in the country of origin. Using a quantitative methodological approach, of a descriptive nature, it explored primary data provided by INPI (Instituto Nacional de Propriedade Industrial) and secondary data extracted from the Lattes platform. Considering the two universities that had the largest number of patents published in 2014 - USP and UNICAMP the 30 most productive inventors in the number of patent applications filed in each of the institutions were named. Data on the academic and professional trajectory of 472 researchers were extracted from the CV Lattes of the 282 inventors of USP and 190 of UNICAMP. The results confirm the thesis, thus contributing to the field of studies on IAM and the effects for the countries involved. In addition, when discussing the relationship between IAM, education and applied research with patent application as an indicator of technological innovation, the article presented contributions to the sphere of public policies, especially linked to Science and Technology of the country.
\end{abstract}

Keywords: international academic mobility; education; applied research; technologic innovation; patents.

\section{Mobilidade acadêmica internacional e depósito de patentes no país de origem}

Este artigo tem por objetivo verificar a existência de relação positiva entre a mobilidade acadêmica internacional (MAI) e a inovação (depósito de patentes) no país de origem do talento acadêmico. A tese defendida é que existe relação positiva para o país de origem. Se em um primeiro momento os efeitos positivos dessa relação beneficiam os países de destino, em um segundo momento há efeito positivo para os países de origem. Fazendo uso de abordagem metodológica quantitativa, de caráter descritivo, esta pesquisa explorou dados primários cedidos pelo Instituto Nacional de Propriedade Industrial (INPI) e dados secundários extraídos da Plataforma Lattes. Considerando as duas universidades que reuniram o maior número de patentes publicadas em 2014 - Universidade de São Paulo (USP) e Universidade Estadual de Campinas (Unicamp) — chegou-se ao nome dos 30 inventores mais produtivos em número de patentes depositadas, em cada uma das instituições. Dados relativos à trajetória acadêmica e profissional de 472 pesquisadores foram extraídos da Plataforma Lattes dos 282 inventores da USP e dos 190 da Unicamp. Os resultados confirmam a tese, contribuindo para o campo de estudos sobre a MAI e os efeitos para os países envolvidos. Ademais, este artigo apresenta contribuições para a esfera de políticas públicas vinculadas à ciência e tecnologia do país.

Palavras-chave: mobilidade acadêmica internacional; educação; pesquisa aplicada; inovação tecnológica; patentes.

\section{Movilidad académica internacional y depósito de patentes en el país de origen}

El presente artículo tiene como objetivo verificar la existencia de una relación positiva entre la MAI (movilidad académica internacional) y la innovación (depósito de patentes) en el país de origen del talento académico. La tesis defendida es que existe una relación positiva para el país de origen. Si en un primer momento los efectos positivos de esa relación son para los países de destino, en un segundo momento existe un efecto positivo para los países de origen, respetando la formación de calidad de la trayectoria académica y su posición en instituciones de 
proyección nacional e internacional en el país de origen. Haciendo uso de un abordaje metodológico cuantitativo, de carácter descriptivo, exploró datos primarios cedidos por el INPI (Instituto Nacional de Propriedade Industrial) y secundarios extraídos de la plataforma Lattes. Considerando las dos universidades que reunieron el mayor número de patentes publicadas en 2014 - USP y UNICAMP - se llegó al nombre de los 30 inventores más productivos en número de patentes depositadas en cada una de las instituciones. Los datos relativos a la trayectoria académica y profesional de 472 investigadores fueron extraídos del CV Lattes de los 282 inventores de la USP y de los 190 de la UNICAMP. Los resultados confirman la tesis, luego contribuyendo al campo de estudios sobre la MAI y los efectos para los países involucrados. Además, al discutir la relación entre MAI, educación e investigación aplicada con depósito de patentes como indicador de innovación tecnológica, el artículo presentó contribuciones a la esfera de políticas públicas, en especial vinculadas a la Ciencia y Tecnología del país.

Palabras clave: movilidad académica internacional; educación; investigación aplicada; innovación tecnológica; patentes.

\section{INTRODCTION}

The migratory behavior of highly qualified individuals is considered to be an important mechanism for spreading tacit knowledge. Since knowledge "travels with the people who master it" (Breschi, Lenzi, Lissoni, \& Vezzulli, 2010, p. 17), the circulation of these talents is believed to contribute greatly to enriching the local knowledge base by increasing the availability of valuable human capital and raising the level of creativity and productivity in local interactions (Maré, Fabling, \& Stillman, 2011). The coexistence of distinct sources of tacit knowledge, individually incorporated in the same geographical context, triggers localized processes of cumulative learning (Capello, 2010) and encourages innovative performance in the receiving areas (Asheim \& Coenen 2005; Iammarino, 2005; Asheim \& Gertler, 2006).

The highest rates of qualified emigration are seen to move from nations that have with a low level of development to more developed nations (Gibson \& McKenzie, 2014). Thus, an eventual "brain drain" of researchers leaving their countries of origin raises arguments about commitment to the local innovation capability. In contrast, there is the argument that a highly-qualified diaspora may facilitate the transfer of knowledge between the countries to which the researchers move and their countries of origin. Examples of qualified diasporas able to promote innovation and economic growth are those business-people who originated in China, India and Taiwan. They returned from Silicon Valley in significant numbers to invest in their countries of origin (Saxenian, 2006). Similarly, in the academic world it is argued that scientists who take part in international academic mobility (IAM) programs play an important role in the process of transferring cutting-edge technology to the nations involved (Kerr, 2008). IAM expands collaboration networks and enables projects that are global in their scope and reach (Doring \& Schnellenbach, 2006; Miguelez \& Moreno, 2013).

It seems, therefore, that IAM stimulates innovation in the countries involved. The central concern of this article, however, is a particular situation that is common to all countries involved with IAM, especially the countries of origin of academic talents. After the IAM program of academic talent was introduced, one of the great hopes of the nations of origin has been that this talent will return to some national institution. In this situation, the central question is:

- After returning to their country of origin, do the talents who took part in IAM continue being innovative? 
The main objective of this article, therefore, is to understand if IAM fosters innovation in academic talents after their return to the country of origin. In order to do so, we undertook a descriptive analysis of data that were made available by the National Institute of Industrial Property (INPI) and data obtained from consulting the Lattes Platform. The research universe consisted of 78 invention patents that were filed by 282 inventors linked to the University of São Paulo (USP) and 60 invention patents filed by 190 inventors linked to the State University of Campinas (Unicamp).

Based on this questioning, the study discusses the literature about IAM and patent filing. While the literature (Acs, Anselin, \& Varga, 2002; Burhan, Singh, \& Jain, 2016; Han, Stocking, Gebbie, \& Appelbaum, 2015) focuses on the direct effect on the destination country, this article argues that there is also a positive impact on the country of origin. Although patents can be initially filed abroad in the place to which the researcher moves in their IAM, it is argued that the stock of accumulated knowledge and the path the researcher follows abroad favor the filing of patents when they return and work in institutions in their country of origin.

This is of utmost importance to Brazil, since most of the internationalization process of higher education institutions (HEIs) is still a passive occurrence (Lima \& Contel, 2011) and one that focuses on the IAM of PhDs, post-doctoral students and teachers (Coordinating Office for the Further Education of Higher-level Personnel [CAPES], 2017). As a consequence, understanding whether IAM boosts innovation not only contributes by providing a new perspective on the literature, but helps with the strategic direction of public policies for science and technology.

\section{REVIEW OF THE LITERATURE}

Siekierski, Lima, Borini, and Pereira (2018) recently undertook a literature review in order to understand the relationship between IAM and different dimensions related to innovation. The results revealed that the effects of IAM vary according to the dimension analyzed, but it does have a positive impact on innovation in both the country of origin and country of destination. Most of the literature (Beine, Defoort, \& Docquier, 2011; Chepurenko, 2014; Cheung \& Xu, 2015; Eisenberg et al., 2013; Heitor, Horta, \& Mendonça, Cruz-Castro, 2013; Jonkers \& Tijssen, 2008; Richardson \& Mallon, 2005; Velema, 2012) confirms that IAM improves the quality of academic human resources in the country of origin. In turn, the impact on publications (Azoulay, Ganguli, \& Zivin, 2016; Geuna et al., 2015; Hoekmana, Frenken, \& Tijssen, 2010; Jonkers \& Cruz-Castro, 2013; Jonkers \& Tijssen, 2008; Kato \& Ando, 2013; Velema, 2012; Veugelers, 2010; Zubieta-Fernández, Geuna, \& Lawson, 2016) and the formation of networks of researchers are positive for both countries of origin and destination (Chepurenko, 2014; Dobson \& Hölttä, 2010; Heitor et al., 2014; Jonkers \& Tijssen, 2008; Niu, 2014; Sambunjak \& Marušić, 2011; Velema, 2012; Veugelers, 2010). With regard to the filing of patents, however, most of the studies (Acs et al., 2002; Burhan et al., 2016; Han et al., 2015) find the impact to be positive for the country of destination. It is this last dimension that of filing patents, that this article deals with. To do so it will investigate the conversion of knowledge for industrial application and to what extent investment in public IAM policies can be converted into innovation that is applied in the country.

Government-funded research promotion agencies are considered to be an integral part of the National Innovation System (SNI) and necessary for promoting research that is oriented towards the development and strengthening of Brazil's innovation capabilities. Patenting rates have been 
widely used as indicators for measuring technological innovation (Burhan et al., 2016; Nilsson, 2013). The number of patents filed by a country is one of the main indicators of the index of scientific and technological innovation (Global Innovation Index, 2017). This idea is reinforced by Acs et al. (2002); for these authors, the number of patents filed by a particular country is a representation of its innovation activity.

Stokes (2005) differentiates between the contribution made by science and engineering in the same university. While science courses are committed to producing new knowledge, engineering courses are committed to applying existing and emerging knowledge for solving specific technical problems (Stokes, 2005). For government agencies they are complementary, to the extent that engineering uses the knowledge of science, which is indispensable when it comes to solving social problems.

In light of the above, it would seem to be important for countries to define subsidy policies that are consistent with what they want, as this will directly affect the productivity of inventors in terms of publications and the filing of patents. Understandably, investing in relationships that bring together universities, industry and government is fundamental for collaborative work, career transitions, and the results achieved by the professionals involved. For Schwartzman (2002), research needs to be brought closer to the production sector, because when the interaction between research institutions and the public sector is strengthened, it attracts more academics and more competences. Productivity increases not just when industry cooperates with academia, but also conversely when academia cooperates with industry (Bozeman \& Corley, 2004; Bozeman, Dietz, \& Gaughan, 2001; Bozeman \& Rogers, 2002; Dietz, 2000; Dietz \& Bozeman, 2005; Siegel, Waldman, \& Link, 2003).

\subsection{Central Proposition}

As already pointed out in relation to the filing of patents, most of the studies (Acs et al., 2002; Burhan et al., 2016; Han et al., 2015) restrict themselves to discussing the positive impact on the country of destination. This position seems alarming given Brazilian IAM. It is worth highlighting the growth there has been in the IAM of academic talents in the context of Brazil. Over the last 10 years (2008 to 2017), the number of those awarded sandwich PhD scholarships by the Coordinating Office for the Further Education of Higher-level Personnel (CAPES) increased from 1,548 to 4,890 in the period, with peaks that exceeded this final number in both 2014 and 2015. In all, more than 32,000 academics received sandwich $\mathrm{PhD}$ scholarships to study abroad in this period. Likewise, the number of those on fulltime $\mathrm{PhD}$ scholarships abroad went from 715 to 1,975 , again with peaks in 2014 and 2015, for a total of 13,320 scholarship students. Finally, according to Geo Capes (2018), in the period considered more than 9,000 academics were doing a post-doctoral internship abroad. Added to these figures are the scholarship holders on the Science Without Borders (2011-2016) program, which gave 92,880 scholarships abroad, although almost $80 \%$ of them were intended for graduate students (Silva Cavalcante, Guedes, \& Araújo Püschel, 2018). In the report "Internationalization in Brazilian universities" (CAPES, 2017), the modalities of post-doctoral teachers and sandwich $\mathrm{PhD}$ course students abroad are those that appear first in terms of the internationalization strategies of HEIs.

These figures attest to the growth in the IAM of HEIs as the main internationalization strategy for graduate programs (GPs) (Ramos, 2018). Even though it results from the passive internationalization 
of HEIs (Lima, 2008, Lima \& Contel, 2011), the IAM described above tends to persist, despite the pressures that are exerted by CAPES towards a more active internationalization, which was encouraged by publication of Invitation to Bid No. 41/2017, in the final days of the year, which gave rise to the Institutional Internationalization Program (CAPES-PrInt).

In line with this finding, the question is whether it would be prudent to promote public policies that encourage this IAM, since the literature does not point to any relationship with patent filings (Acs et al., 2002; Burhan et al., 2016; Han et al., 2015).

We believe that the answer to the above question is positive. It is not a matter of contradicting literature, but of assessing the question of innovation and, more specifically, the filing of patents as one of the outcomes of the career path of a researcher. If the analysis were to be the filing of patents right after IAM, the beneficiary will undoubtedly be the receiving country, or another country in the international research network of which the researcher was part during their internship abroad (Cheung \& Xu, 2015; Poutvaara \& Dreher, 2011; Tremblay, 2000). When analyzing the researcher's journey, however, we believe that IAM also has a long-term impact; when the researcher returns to their country of origin they have the skills needed and the potential to work as an innovative teacherresearcher, capable of having a positive influence on the formation of innovative academics and of becoming a member of or leading national and international innovation networks. When installed in Brazilian cutting-edge institutions with an adequate infrastructure, the theoretical, methodological and technical repertoire achieved by participating in an IAM program reverts in innovation results over time. Therefore, considering IAM to be one of the stages in an academic career, as is the return to the country of origin, the association between IAM and patents tends to be positive. This means that:

- Central proposition: The IAM of academic talents is also associated with the filing of patents in the country of origin.

\section{METHODOLOGY}

According to the Global Innovation Index (2017), a patent is the exclusive right granted to an invention. Invention, in its turn, is a product or a process that generally contributes to a new way of doing something, or offers a new technical solution to a problem. To obtain a patent, technical information about the invention must be disclosed to the public in a patent application. Patents are not just abstract concepts. They are of practical importance in everyday life; they encourage the development of innovations and they may generate new technologies in all fields of knowledge. One of the main functions of the patent system is promoting technological innovation, thus providing an incentive for R \& D. The patent system also works to break down technical information into component parts and promote the transfer of technology.

With the purpose of studying the relationship between IAM and patent filing, we caried out a quantitative study in which we looked at both primary and secondary data. We used descriptive analysis for the data that were collected from primary databases provided by INPI, and from secondary databases extracted from the Lattes Platform. Although the spreadsheets supplied by INPI contained data for 2014, they were the most recently available at the time the research was conducted. This is due to the fact that the institute maintains the confidentiality of patent applications for up to 18 months from the date the patent is filed, the time it takes until its publication. The abovementioned patents 
discriminate the number of applications for registration by type of patent (invention, or utility model), date of filing, title and summary of the invention, inventor's name, name and addess of the applicant, and the name of the depositor's university or company to whch they are affiliated.

It has to be pointed out that a patent gives temporary title to an invention or utility model and is granted by the State to the inventor, as the individual or legal entity that owns the rights of what has been created. There are different types of patent; while the invention patent (IP) is associated with inventive products or processes that have an industrial application, the utility model patent is associated with the functional improvement introduced to an existing product. While the IP is valid for 20 years, the utility model patent is limited to 15 years and this period counts from the filing date (Brazilian Institute of Industrial Property [INPI], 2017). In this article we consider data relating to inventors on the IP ranking (INPI, 2014), since these are new products or processes resulting from discoveries of scientific principles hitherto unknown, and because of this they are responsible for generating innovation that is applicable to industry.

By cross-referencing the name of the author of the patent with the name of the university or company of affiliation, we can see that USP and Unicamp account for most of those responsible for the invention patents that were filed in the period. With the help of a collection protocol, the next step was to systematize consultation of the inventors' résumés in databases that are publicly available (Lattes Platform). The objective behind extracting, organizing and interpreting data was to check whether there is a positive relationship between the number of patents filed by the inventors and their exposure to the international academic environment, their academic background and the fact that their choice of career is oriented more towards applied (technological) research that is aligned with industry interests.

In order to establish limits for our empirical field of research, we decided to explore data that relate to the authors of invention patents who are linked to USP and Unicamp, because these Brazilian institutions were responsible for the largest number of patents registered in 2014. As a consequence, the academic and professional career paths of 472 researchers were taken into account; 282 of them linked to USP and the authors of 78 patents; and 190 of them linked to Unicamp and the authors of 60 patents. In terms of procedure, the résumés of the 472 inventors that are available on the Lattes Platform (Currículo Lattes) were consulted; with this, we were able to check the number of patents they filed up until 2017, the last time Currículo Lattes was updated.

Next, we selected the 30 most productive inventors from each of the universities in terms of the number of patents they had filed. Considering this sample, we analyzed the academic and professional experience of the inventors, taking into account their education, their participation in an IAM program and the area in which each of them works. In the first group, USP's 30 most productive inventors filed 436 patents, while in the second group, Unicamp's 30 most productive inventors filed 426 patents. We can see that the two groups filed approximately the same numbers of patents.

\section{RESULTS}

Consultation of the Curriculo Lattes with regard to the 30 most productive USP inventors in terms of the number of patents filed up until 2017 (Box 1) enables us to state that they are predominantly male inventors (73\%), with $20 \%$ of them having surnames that are Oriental in origin (Koiti Araki, Henrique Eisi Toma, Chung Man Chin, Cristina Kurachi, Sergio Hiroshi Toma, and Tomie Toyota 
de Campos). This is possibly due to the strong immigration from the East in the State of São Paulo. Almost all (97\%) have both a $\mathrm{PhD}$ and attended a post-doctoral internship; 63\% participated in an IAM program, predominantly in countries with a tradition in welcoming international, Englishspeaking academics: the United States (37\%) and the United Kingdom (17\%), while 23\% studied in more than one country. Almost all of them (97\%) come from areas that are particularly used to having close dialogue with industry: Engineering (9), Chemistry (8), Pharmacology (7), Dentistry (2), Biological Sciences (2), Physics and Medicine (1).

\section{BOX 1}

INVENTORS OF PATENTS LINKED TO USP (2014) IAM, EDUCATION AND APPLIED RESEARCH (2017)

\begin{tabular}{|c|c|c|c|c|c|}
\hline Inventor's name & IAM & Education & Applied research & $\begin{array}{l}\text { Number of } \\
\text { patents filed }\end{array}$ & $\begin{array}{l}\text { Date updated } \\
\text { in Currículo } \\
\text { Lattes }\end{array}$ \\
\hline Koiti Araki & Japan; USA & Post-Doc & Chemical Engineering & 40 & 9/2017 \\
\hline $\begin{array}{l}\text { Vanderlei Salvador } \\
\text { Bagnato }\end{array}$ & USA & Post-Doc & Materials Engineering & 34 & 9/2017 \\
\hline Oswaldo Luiz Alves & France & Post-Doc & Chemistry & 33 & 8/2017 \\
\hline Henrique Eisi Toma & USA & Post-Doc & Chemistry & 32 & $7 / 2017$ \\
\hline $\begin{array}{l}\text { Benedito Moraes } \\
\text { Purquerio }\end{array}$ & UK & Post-Doc & Mechanical Engineering & 26 & $8 / 2017$ \\
\hline Edgar Poiate Junior & Brazil & $\mathrm{PhD}$ & $\begin{array}{c}\text { Civil Engineering and Mechanical } \\
\text { Engineering }\end{array}$ & 23 & $5 / 2017$ \\
\hline Chung Man Chin & Brazil & $\mathrm{PhD}$ & Pharmacy/Biochemistry & 21 & 10/2017 \\
\hline Marcelo Dias Baruffi & USA & Post-Doc & Pharmacy/Biochemistry & 19 & 9/2017 \\
\hline Cristina Kurachi & USA & Post-Doc & Materials Engineering & 18 & 9/2017 \\
\hline Valtencir Zucolotto & France; USA & Post-Doc & Materials Engineering & 18 & $10 / 2017$ \\
\hline Isis Andréa Pola Poiate & Brazil & Post-Doc & Dentistry & 14 & $3 / 2017$ \\
\hline Sergio Hiroshi Toma & Brazil & Post-Doc & Chemistry & 12 & $7 / 2017$ \\
\hline $\begin{array}{l}\text { José Otávio Carrera } \\
\text { Silva Junior }\end{array}$ & Italy; Argentina & $\mathrm{PhD}$. & Pharmacy & 11 & 10/2017 \\
\hline $\begin{array}{l}\text { Ronaldo Domingues } \\
\text { Mansano }\end{array}$ & Brazil & $\mathrm{PhD}$ & Electrical Engineering & 10 & $8 / 2017$ \\
\hline $\begin{array}{l}\text { Priscila Fernanda } \\
\text { Campos Menezes }\end{array}$ & Brazil & Post-Doc & Pharmacy/Biochemistry & 10 & 6/2017 \\
\hline
\end{tabular}




\begin{tabular}{|c|c|c|c|c|c|}
\hline Inventor's name & IAM & Education & Applied research & $\begin{array}{l}\text { Number of } \\
\text { patents filed }\end{array}$ & $\begin{array}{l}\text { Date updated } \\
\text { in Currículo } \\
\text { Lattes }\end{array}$ \\
\hline Tomie Toyota Campos & Japan & Post-Doc & Dentistry & 10 & $7 / 2017$ \\
\hline Sergio de Albuquerque & Brazil & $\mathrm{PhD}$ & Animal Biology & 9 & 9/2017 \\
\hline $\begin{array}{l}\text { Ana Maria Carmona } \\
\text { Ribeiro }\end{array}$ & Australia; UK & $\mathrm{PhD}$ & Physics/Biochemistry & 9 & 10/2017 \\
\hline $\begin{array}{l}\text { Maria Fátima Graças } \\
\text { Fernandes Silva }\end{array}$ & UK & Post-Doc & Chemistry & 8 & 9/2017 \\
\hline $\begin{array}{l}\text { João Batista } \\
\text { Fernandes }\end{array}$ & UK & Post-Doc & Chemistry & 8 & 9/2017 \\
\hline Osvaldo Antonio Serra & USA & Post-Doc & Chemistry & 8 & $3 / 2017$ \\
\hline $\begin{array}{l}\text { Jorge Vicente Lopes } \\
\text { Silva }\end{array}$ & Brazil & $\mathrm{PhD}$ & Electrical Engineering & 8 & 10/2017 \\
\hline $\begin{array}{l}\text { Nadia Araci Bou- } \\
\text { Chacra }\end{array}$ & $\begin{array}{l}\text { Germany; USA; } \\
\text { Canada }\end{array}$ & Post-Doc & Pharmaceutical Medicine & 8 & $8 / 2017$ \\
\hline $\begin{array}{l}\text { Patricia Maria Berardo } \\
\text { Gonçalves Maia } \\
\text { Campos }\end{array}$ & UK & Post-Doc & Pharmaceutical Medicine & 7 & 9/2017 \\
\hline Dimas Tadeu Covas & Brazil & $\mathrm{PhD}$ & Medicine & 7 & $8 / 2017$ \\
\hline Roberto Ruller & Brazil & Post-Doc & Chemistry/Biochemistry & 7 & 9/2017 \\
\hline $\begin{array}{l}\text { Luis Carlos de Souza } \\
\text { Ferreira }\end{array}$ & $\begin{array}{l}\text { Germany; } \\
\text { Sweden }\end{array}$ & Post-Doc & Biological Sciences & 7 & 10/2017 \\
\hline Ebert Seixas Hanna & USA & Post-Doc & Pharmacy/Biochemistry & 7 & 10/2017 \\
\hline Moacir Rossi Forim & Canada & Post-Doc & Chemistry & 6 & 9/2017 \\
\hline Anderson Luis Zanchin & Brazil & Master's & Electrical Engineering & 6 & $8 / 2017$ \\
\hline
\end{tabular}

Source: Elaborated by the authors.

Consultation of the Currículo Lattes with regard to the 30 Unicamp inventors who are considered the most productive in terms of the number of patents filed up up until 2017 (Box 2) refers to observations that are similar to those of the group of inventors from USP: more than three quarters of them are male (77\%); and 20\% have surnames that suggest they are Oriental in origin (Araki, Eisi Toma, Man Chun, Kurachi, Hiroshi Toma). All of them (100\%) have a both a $\mathrm{PhD}$ and a post-doctoral internship. Of these, $80 \%$ participated in an IAM program in countries that have a well-known tradition in welcoming international academics. In this case, we see a greater diversification in the countries: USA (33\%), Germany (13\%) France (13\%), UK (10\%) and Canada (10\%); while 23\% studied in more than one country. Almost all of them (93\%) are from areas that have a particularly close dialogue with industry - Engineering (11), Chemistry (5), Biological Sciences (5), Dentistry (3), Computing (2), Medicine, Pharmacology (1), Nutrition (1) and Immunology (1). 

IAM, EDUCATION AND APPLIED RESEARCH (2017)

\begin{tabular}{|c|c|c|c|c|c|}
\hline Inventor's name & IAM & Education & Applied research & $\begin{array}{l}\text { Number of } \\
\text { patents filed }\end{array}$ & $\begin{array}{l}\text { Date updated in } \\
\text { Currículo Lattes }\end{array}$ \\
\hline $\begin{array}{l}\text { Nelson Eduardo Duran } \\
\text { Caballero }\end{array}$ & Chile; Puerto Rico & Post-Doc & Chemistry & 64 & $8 / 2017$ \\
\hline Rubens Maciel Filho & UK & $\mathrm{PhD}$ & Chemical Engineering & 39 & 9/2017 \\
\hline Oswaldo Luiz Alves & France & Post-Doc & Dentistry & 33 & 8/2017 \\
\hline Lauro Tatsuo Kubota & Sweden & & Chemistry & 24 & $5 / 2017$ \\
\hline $\begin{array}{c}\text { Jarbas José Rodrigues } \\
\text { Rohwedder }\end{array}$ & Brazil & $\mathrm{PhD}$ & Chemistry & 18 & $1 / 2017$ \\
\hline Evandro Conforti & USA; Canada & Post-Doc & Electronic Engineering & 16 & 9/2017 \\
\hline Gerson Nakazato & Brazil & PhD & $\begin{array}{l}\text { Genetics/Molecular } \\
\text { Biology }\end{array}$ & 15 & 10/2017 \\
\hline Francisco Maugeri Filho & UK & Post-Doc & Food Engineering & 14 & $1 / 2017$ \\
\hline Marcelo Lancellotti & France & Post-Doc & $\begin{array}{l}\text { Genetics/Molecular } \\
\text { Biology }\end{array}$ & 13 & $8 / 2017$ \\
\hline $\begin{array}{c}\text { Renata Katsuko Takayama } \\
\text { Kobayashi }\end{array}$ & Canada & Post-Doc & Microbiology & 12 & 9/2017 \\
\hline Ricardo Mathias Orlando & Brazil & Post-Doc & Chemistry & 12 & $5 / 2017$ \\
\hline $\begin{array}{c}\text { Rodney Alexandre Ferreira } \\
\text { Rodrigues }\end{array}$ & Brazil & $\mathrm{PhD}$ & Food/Nutrition & 12 & $7 / 2017$ \\
\hline Célio Pasquini & UK & Post-Doc & Chemical Engineering & 11 & 9/2017 \\
\hline João Ernesto de Carvalho & USA; Belgium & $\mathrm{PhD}$ & Pharmacology & 11 & $8 / 2017$ \\
\hline Cristiano de Mello Gallep & Netherlands & Post-Doc & Electrical Engineering & 11 & 9/2017 \\
\hline Luciana Maria de Hollanda & Brazil & Post-Doc & $\begin{array}{l}\text { Genetics/Molecular } \\
\text { Biology }\end{array}$ & 10 & 10/2017 \\
\hline $\begin{array}{l}\text { Mário Alexandre Coelho } \\
\text { Sinhoreti }\end{array}$ & USA & Post-Doc & Dentistry & 10 & 10/2017 \\
\hline Anderson de Rezende Rocha & USA & Post-Doc & Computer Science & 9 & $5 / 2017$ \\
\hline Marcelo Menossi Teixeira & Spain & Post-Doc & Biological Sciences & 9 & $8 / 2017$ \\
\hline Lucimara Gaziola de la Torre & France; Germany & Post-Doc & Chemical Engineering & 8 & 9/2017 \\
\hline $\begin{array}{c}\text { Maria de Lourdes Setsuko } \\
\text { Ayrizono }\end{array}$ & Brazil & $\mathrm{PhD}$ & Medicine & 8 & $8 / 2017$ \\
\hline $\begin{array}{c}\text { Aline Ferreira de Oliveira } \\
\text { Pereira }\end{array}$ & USA & Post-Doc & $\begin{array}{l}\text { Basic \& Applied } \\
\text { Immunology }\end{array}$ & 7 & $12 / 2016$ \\
\hline Antonio Carlos Banwart & USA; France & Post-Doc & Mechanical Engineering & 7 & $7 / 2017$ \\
\hline
\end{tabular}




\begin{tabular}{|c|c|c|c|c|c|}
\hline Inventor's name & IAM & Education & Applied research & $\begin{array}{l}\text { Number of } \\
\text { patents filed }\end{array}$ & $\begin{array}{l}\text { Date updated in } \\
\text { Currículo Lattes }\end{array}$ \\
\hline Fábio Rogério Piva & Germany & $\mathrm{PhD}$ & Computer Science & 7 & $8 / 2017$ \\
\hline Lee Luan Ling & USA & Post-Doc & Electrical Engineering & 7 & $11 / 2016$ \\
\hline Susanne Rath & Germany & Post-Doc & $\begin{array}{l}\text { Pharmaceutical } \\
\text { Chemistry }\end{array}$ & 7 & $7 / 2017$ \\
\hline $\begin{array}{l}\text { Dayane Carvalho Ramos } \\
\text { Salles de Oliveira }\end{array}$ & USA & Post-Doc & Dentistry & 7 & 9/2017 \\
\hline Ernesto Ruppert Filho & Canada & Post-Doc & Electrical Engineering & 6 & $3 / 2017$ \\
\hline $\begin{array}{c}\text { Max Henrique Machado } \\
\text { Costa }\end{array}$ & USA; Germany & Post-Doc & Electrical Engineering & 6 & $4 / 2017$ \\
\hline Théo Guenter Kieckbusch & USA & Post-Doc & Food Engineering & 6 & 9/2017 \\
\hline
\end{tabular}

Source: Elaborated by the authors.

\section{DISCUSSION OF THE RESULTS}

The data show that the greater the number of patents filed, the higher the academic level attained and the greater the participation of inventors in IAM programs. While $97 \%$ of USP's 30 most productive inventors have both a $\mathrm{PhD}$ and done a post-doctoral internship, this is true of all (100\%) of those from Unicamp. Exposure to the international academic environment is equally representative: while $63 \%$ of USP's inventors participated in IAM programs, this occurred with $80 \%$ of the inventors from Unicamp. Among the data set out in Box 1 (USP) and Box 2 (Unicamp) we include the field of knowledge of the inventors. In the case of USP, 97\% work in the areas of Science, Technology, Engineering and Math (STEM), and in the case of Unicamp this figure is $93 \%$.

We observe, therefore, that the association between a strong academic background and exposure to the international academic environment are factors that have an influence on the filing of patents. In addition to working in one of the two Brazilian universities with the greatest national and international projection ${ }^{1}$, a large number of the inventors not only have a $\mathrm{PhD}$, but also attended a post-doctoral internship in international universities that are renowned for their research. Their academic backgrounds and the professional activity of the inventors who filed most patents are concentrated in the STEM areas, as pointed out by Stokes (2005) when dealing with the centrality of applied science in the process of technological innovation. This means that the findings allow us to infer a complementary position in the relationship between IAM and patent filing (Acs et al., 2002; Burhan et al., 2016; Han et al., 2015). The beneficiary may initially be the country of destination, but subsequently the beneficiary is also the country of origin thanks to the synergy that exists between IAM and academic formation and working in institutions of national and international projection

\footnotetext{
${ }^{1}$ The international recognition of the two institutions is obvious from the positions thay occupy in world and regional rankings. Considering the results for 2016/2017 taken from the Times Higher Education (n.d.), while USP is 2nd (Latin America), 13th (BRICS) and between 251-300 (World) in the respective rankings, Unicamp is 1st (Latin America), 28th (BRICS) and between 401-500 (World). These are prominent positions when one takes into account how young both universities are.
} 
in the territory of origin. This is where the main contribution of this study to IAM literature lies; that is, it divides the benefit of filing patents into distinct moments in the career of the academic talent participating in an IAM program. In short, there is a positive relationship between IAM and filing patents in the long term, provided that the conditions of academic background and the infrastructure of the institutions are met. This finding corroborates the conclusions of Hoisl (2007), for whom the generation of patents is more recurrent among inventors with a strong academic background. Participation in IAM programs affects productivity to the extent that it is associated with a process of searching for and exchanging know-how. Access to external sources of knowledge can have a positive influence on inventor productivity.

The results of our research underline the role that government can play in formulating consistent public policies that are capable of supporting the development of science, technology and innovation (STI) in the country, and more specifically the internationalization of HEIs and IAM programs (CAPES, 2017). The virtuous relationship between government, university and industry is stressed by Carlos Henrique de Brito Cruz, scientific director of the São Paulo Research Foundation (FAPESP). Cruz (2017) believes that while academia contributes to the generation of new knowledge and to the academic formation of researchers, companies have a central role to play in the innovation process that will greatly influence the competitiveness of the production sector, which are factors that can favor the promotion of sustainable social and economic development. Along these same lines, Dr Alexandre Lopes Lourenço, who is responsible for the General Coordination of Studies, Projects and the Dissemination of Technological Information (CEPIT) of the National Institute of Industrial Property (INPI), Brazil would gain a lot if there were closer contact between the representatives of basic science and applied science through collaborative work between universities, industry and government. The author guarantees that while the USA, Japan and South Korea recognize the relevance of applied (technological) research for solving practical problems, the emphasis in Brazil is on basic (scientific) research, since researcher recognition is heavily associated with the number of scientific papers they have published in high impact journals.

In this sense, the results reaffirm the triple helix model (Etzkowitz, 2009), which strengthens and brings the research university and the entrepreneurial university closer together, particularly when the STEM areas are taken into account. The results of this alliance can radiate in various directions, as do state actions. For example, the Chinese government adopts a policy of repatriating researchers. This involves highly qualified professionals who are members of international research networks and who, after building a solid academic career abroad, indicate their interest in participating in repatriation programs and are encouraged to do so through tax incentives, housing assistance and research funding (Han et al., 2015).

In government public policies, therefore, we believe that the results support the virtuous cycle of innovation developed by Gilder (2012), in which scientific and technical knowledge represents an opportunity for dynamic growth to generate investments, jobs, income and consumption. The formulation of public policies that are consistent with IAM and the internationalization of HEIs can favor the formation of senior personnel in areas considered strategic for the country, but policies that face up to the institutional, economic and mainly cultural barriers related to innovation are also necessary. For this to happen, instruments that regulate the relationship between scientific and 
technological production need to be developed. Matias-Pereira and Kruglianskas (2005) undertook research into the management of innovation in Brazil and guarantee that the country produces cuttingedge science, but is still unable to interact at an appropriate level with the production sector. They warn that the result of this poor incorporation of state-of-the-art technology in products makes them uncompetitive, both in the domestic market and abroad. Like in South Korea, the country needs a Ministry of Science and Technology that can co-ordinate various interdisciplinary and strategic areas and equitably articulate ministries and agencies so that the elements of the triple helix (Etzkowitz, 2009) university - industry - government are aligned.

\section{FINAL CONSIDERATIONS}

The central issue that guided this article was the existence of a positive relationship between IAM and innovation (filing patents) in the country of origin of academic talent. While the literature argues that this positive association for the country of destination exists, here we proposed a complementary thesis to this current view. While initially the positive effects of this relationship benefit the destination countries, there is subsequently a positive effect for the countries of origin, provided the academic path of the inventors comprises a quality education and they are associated with institutions of national and international projection in the country of origin. Using a quantitative methodological approach of a descriptive nature, we explored primary data that were provided by INPI and secondary data that were extracted from the Lattes Platform. Considering the two universities that had the largest number of patents published in 2014 - USP and Unicamp - we obtained the names of the 30 most productive inventors in each institution, by number of patents filed. Data relating to the academic and professional career path of 472 researchers were extracted from the Currículo Lattes of the 282 inventors from USP and 190 from Unicamp. The results confirm the thesis and so contribute to the field of studies on IAM and the effects on the countries involved. Furthermore, by discussing the relationship between IAM, education and applied research and filing patents as an indicator of technological innovation, this article makes a contribution to the sphere of public policies, especially those related to science and technology in the country.

This study has its limitations. We undertook a descriptive analysis of the data collected by INPI and those extracted from the Lattes Platform that refer to those responsible for generating patents. In concluding the article, we believe the results achieved could advance if the most productive inventors, both those linked to universities and those linked to industry, were heard by way of in-depth interviews. Since they are highly qualified and professionally experienced academics, the material resulting from the interviews could be used as the basis for more advanced description and analysis exercises. Another limitation refers to the fact that the companies were not analyzed as patent filing agents and the recipients of academic talents. Considering that large Brazilian companies have become international and sought to achieve excellence in processes and results by adopting good management practices and investing in innovation, one of the possibilities for continuing this line of research would be to replicate it in Brazil's most productive companies in terms of the number of patents filed. Whirlpool S.A., Petrobrás S.A., Vale S.A., Randon S.A., Embraer S.A., Embrapa and Marco Polo S.A. would be examples of companies that could be included in the sample. 


\section{REFERENCES}

Acs, Z., Anselin, L., \& Varga, A. (2002). Patents and innovation counts as measure of regional production of new knowledge. Research Policy, 31(7), 1069-1085.

Asheim, B., \& Coenen, L. (2005). Knowledge bases and regional innovation systems: comparing Nordic clusters. Research Policy, 34(8), 1173-1190.

Asheim, B., \& Gertler, M. (2006). The geography of innovation: regional innovation systems. In J. Fagerberg, D. C. Mowery, \& R. R. Nelson (Eds.), The Oxford handbook of innovation (pp. 291-317). Oxford, England: Oxford University Press.

Azoulay, P., Ganguli, I., \& Zivin, J. G. (2016). The mobility of elite life scientists: professional and personal determinants. Research Policy, 46(3), 573590.

Beine, M., Defoort, C., \& Docquier, F. (2011). A panel data analysis of the brain drain. World Development, 39(4), 1-33.

Bozeman, B., \& Corley, E. (2004). Scientist's collaboration strategies: implications for scientific and technical human capital. Research Policy, 33(4), 599-616.

Bozeman, B., Dietz, S. J., \& Gaughan, M. (2001). Scientific and technical human capital: an alternative model for research evaluation. International Journal of Technology Management, 22(7), 716-740.

Bozeman, B., \& Rogers, D. J. (2002). A churn model of scientific knowledge value: Internet researchers as a knowledge value collective. Research Policy, 31(5), 769-794.

Breschi, S., Lenzi, C., Lissoni, F., \& Vezzulli, A. (2010). The geography of knowledge spillovers: the role of inventors' mobility across firms and in space. In R. Boschma, \& R. Martin (Eds.), The handbook of evolutionary economic geography (chap. 16, pp. 576592). Cheltenham, England: Edward Elgar.

Burhan, M., Singh, A., \& Jain, S. (2016). Patents as a proxy for measuring innovations: a case of changing patent filing behavior in Indian public funded research organizations. Technological Forecasting and Social Change, 123, 181-190.

Capello, R. (2010). Spatial transfer of knowledge in high technology milieux: learning versus collective learning processes. Regional Studies, 33(4), 353-365.
Chepurenko, A. (2014). The role of foreign scientific foundations' role in the cross-border mobility of Russian academics. International Journal of Manpower, 36(4), 562-584.

Cheung, A. C. K., \& Xu, L. (2015). To return or not to return: examining the return intentions of mainland Chinese students studying at elite universities in the United States. Studies in Higher Education, 40(9), 1605-1624.

Coordenação de Aperfeiçoamento de Pessoal de Nível Superior. (2017). A internacionalização na universidade brasileira: resultados do questionário aplicado pela Capes. Brasília, DF: Author.

Cruz, C. H. B. (2017). "O Brasil não premia quem corre riscos", diz Brito Cruz, da Fapesp. Retrieved from http://epocanegocios.globo.com/Brasil/ noticia/2017/05/nao-ta-tranquilo-nem-favoravelmas-arriscar-para-que.html

Dietz, S. J. (2000). Building a social capital model of research development: the case of the experimental program to stimulate competitive research. Science and Public Policy, 27(2), 137-145.

Dietz, S. J., \& Bozeman, B. (2005). Academic careers, patents and productivity: industry experience as scientific and technical human capital. Research Policy, 34(3), 349-367.

Dobson, I. R., \& Hölttä, S. (2010). The internationalisation of university education: Australia and Finland compared. Tertiary Education and Management, 7(3), 243-254.

Doring, T., \& Schnellenbach, J. (2006). What do we know about geographical knowledge spillovers and regional growth? A survey of the literature. Regional Studies, 40(3), 375-395.

Eisenberg, J., Lee, H.-J., Bruck, F., Brenner, B., Claes, M. T., Mironski, J., \& Bell, R. (2013). Can business schools make students culturally competent? Effects of cross-cultural management courses on cultural intelligence. Academy of Management Learning \& Education, 12(4), 603-621.

Etzkowitz, H. (2009). Hélice tríplice: universidadeindústria-governo: inovação em movimento. Porto Alegre, RS: Ed. PUCRS.

Geuna, A., Kataishi, R., Toselli, M., Guzmán, E., Lawson, C., Zubieta-Fernández, A., \& Barros, B. 
(2015). SiSOB data extraction and codification: a tool to analyze scientific careers. Research Policy, 44(9), 1645-1658.

Geo Capes (2018). Sistema de Informações Georreferenciadas / CAPES. Retrieved from https:// geocapes.capes.gov.br/geocapes/ (2018).

Gibson, J., \& Mckenzie, D. (2014). Scientific mobility and knowledge networks in high emigration countries: evidence from the Pacific. Research Policy, 43(9), 1486-1495.

Gilder, G. (2012). Wealth and poverty: a new edition for the twenty-first century. Washington, DC: Regnery.

Global Innovation Index. (2017). Effective innovation policies for development. Retrieved from https://www. globalinnovationindex.org/analysis-indicator

Han, X., Stocking, G., Gebbie, M., \& Appelbaum, R. (2015). Will they stay or will they go? International graduate students and their decisions to stay or leave the U.S. upon graduation. Plos One, 10(3), 1-18.

Heitor, M., Horta, H., \& Mendonça, J. (2014). Developing human capital and research capacity: science policies promoting brain gain. Technological Forecasting \& Social Change, 82, 6-22.

Hoekmana, J., Frenken, K., \& Tijssen, J. W. R. (2010). Research collaboration at a distance: changing spatial patterns of scientific collaboration within Europe. Reserch Policy, 39(5), 662-673.

Hoisl, K. (2007). Tracing mobile inventors. The causality between inventor mobility and inventor productivity. Research Policy, 36(5), 619-636.

Iammarino, S., Piva, M. C., Vivarelli, M. \& Von Tunzelmann, N. (2012). Technological capabilities and patterns of innovative co-operation of firms in the UK regions, Regional Studies, 46(10), 1283-1301.

Instituto Nacional de Propriedade Industrial. (2014). Ranking dos Depositantes Residentes de Patentes de Invenção (PI) (2014). Retrieved from http://www. inpi.gov.br/sobre/estatisticas/arquivos/estatisticaspreliminares/ranking_2014.pdf

Instituto Nacional de Propriedade Industrial. (2017). Estatísticas, 2017. Retrieved from http://www.inpi. gov.br/sobre/estatisticas

Jonkers, K., \& Cruz-Castro, L. (2013). Research upon return: the effect of international mobility on scientific ties, production and impact. Research Policy, 42(8), 1366-1377.

Jonkers, K., \& Tijssen, R. (2008). Chinese researchers returning home: impacts on international mobility on research collaboration and scientific productivity. Scientometrics, 77(2), 309-333.

Kato, M., \& Ando, A. (2013). The relationship between research performance and international collaboration in chemistry. Scientometrics, 97(3), 535-553.

Kerr, W. (2008). Ethnic scientific communities and international technology diffusion. Review of Economics and Statistics, 90(3), 518-537.

Lima, M. C. (2008). Características atuais das políticas de internacionalização das instituições de educação superior no Brasil. Revista e-Curriculum, $3(2)$.

Lima, M. C., \&Contel, F. B. (2011). Internacionalização da educação superior: nações ativas, nações passivas e a geopolítica do conhecimento. São Paulo, SP: Alameda.

Maré, D., Fabling, R., \& Stillman, S. (2011, April). Immigration and innovation (IZA Discussion Paper No. 5626). Bonn, Germany: IZA — Institute of Labor Economics.

Matias-Pereira, J., \& Kruglianskas, I. (2005). Gestão de inovação: a lei de inovação tecnológica como ferramenta de apoio às políticas industrial e tecnológica do Brasil. RAE-eletrônica, 4(2), 1-22.

Miguelez, E., \& Moreno, R. (2013). Research networks and inventor's mobility as drivers of innovation: evidence from Europe. Regional Studies, 47(10), 1668-1685.

Nilsson, A. (2013). Innovation proxy: a study of patent and economic growth in China (Master's Thesis). Lund University, Lund, Sweden.

Niu, X. S. (2014). International scientific collaboration between Australia and China: a mixedmethodology for investigating the social processes and its implications for national innovation systems. Technological Forecasting \& Social Change, 85, 58-68.

Poutvaara, P., \& Dreher, A. (2011). Foreign students and migration to the United States. World Development, 39(8), 1294-1307. 
Ramos, M. Y. (2018). Internacionalização da pósgraduação no Brasil: lógica e mecanismos. Educação e Pesquisa, 44, e161579.

Richardson, J., \& Mallon, M. (2005). Career interrupted? The case of the self-directed expatriate. Journal of World Business, 40(4), 409-420.

Sambunjak, D., \& Marušić, M. (2011). Between forwarding and mentoring: a qualitative study of recommending medical doctors for international postdoctoral research positions. BMC Medical Education, 11(31), 1-9.

Saxenian, A. L. (2006). The new Argonauts: regional advantage in a global economy. Cambridge, MA: Harvard University Press.

Schwartzman, S. (2002). A pesquisa e o interesse público. Revista Brasileira de Inovação, 1(2), 361-395.

Siegel, D. S., Waldman, D., \& Link, A. (2003). Assessing the impact of organizational practices on the relative productivity of university technology transfer offices: an exploratory study. Research Policy, 32(1), 27-48.

Siekierski, P., Lima, M. C., Borini, F. M., \& Pereira, R. M. (2018). International academic mobility and innovation: a literature review. Journal of Global Mobility, 6(3-4), 285-298.
Silva Cavalcante, I. M., Guedes, G. F., \& Araújo Püschel, V. A. (2018). Mobilidade internacional estudantil de enfermagem da Universidade de São Paulo. Revista Brasileira de Enfermagem, 71, 1715-1722.

Stokes, D. (2005). O quadrante de Pasteur: a ciência básica e a inovação tecnológica. Campinas, SP: Ed. Unicamp.

Times Higher Education. (n.d.). World University Rankings. Retrieved from https://www. timeshighereducation.com/

Tremblay, K. (2000). Student mobility between and towards OECD countries: a comparative analysis. In T. Straubhaar, International mobility of the highly skilled (pp. 39-70. Paris, France: Organisation for Economic Co-Operation and Development.

Velema, T. A. (2012). The contingent nature of brain gain and brain circulation: their foreign context and the impact of return scientists on the scientific community in their country of origin. Scientometrics, 93(3), 893-913.

Veugelers, R. (2010). Towards a multipolar science world: trends and impact. Scientometrics, 82, 439-456.

Zubieta-Fernández, A., Geuna, A., \& Lawson, C. (2016). Productivity pays-off from academic mobility: should I stay or should I go? Industrial and Corporate Change, 25(1), 91-114.

\section{Paulette Siekierski}

https://orcid.org/0000-0002-0753-5134

$\mathrm{PhD}$ student on the Master's and PhD Program in International Management (PMDGI) of Escola Superior de Propaganda e Marketing (ESPM). E-mail: dessi@inwind.it

\section{Manolita Correia Lima}

https://orcid.org/0000-0001-6852-2997

Professor and Coordinator of the Teaching Innovation Center of the Master's and PhD Program in International Management (PMDGI) of Escola Superior de Propaganda e Marketing (ESPM). E-mail: mclima@espm.br

\section{Felipe Mendes Borini}

https://orcid.org/0000-0003-1389-136X

Professor of the Master's and PhD Program in International Management (PMDGI) of Escola Superior de Propaganda e Marketing (ESPM); Professor of the School of Economics \& Administration of the University of São Paulo (FEA-USP). E-mail: fborini@espm.br 